\title{
Identifying the Challenges of the Sarawak Malay Terubok Ikan Masin (Salted Fish) Entrepreneur: Qualitative Study
}

\author{
Jati Kasuma $^{1}$, Niena Nurul Farhana ${ }^{1}$, Hazami Mohammad Kamaruddin ${ }^{1}$, Muhamad Saufi Che Rusuli ${ }^{2} \&$ Yusman \\ $\mathrm{Yacob}^{1}$ \\ ${ }^{1}$ Faculty of Business Management, Universiti Teknologi Mara, Sarawak Branch, Malaysia \\ ${ }^{2}$ Malaysian Graduate School of Entrepreneurship and Business, Universiti Malaysia Kelantan, Malaysia \\ Correspondence: Jati Kasuma, Senior Lecturer, Faculty of Business Management, Universiti Teknologi Mara, \\ Sarawak Branch, Malaysia.
}

Received: May 1, 2019

Accepted: June 1, 2019

Online Published: July 7, 2019

doi:10.5430/rwe.v10n2p30

URL: https://doi.org/10.5430/rwe.v10n2p30

\begin{abstract}
Sarawak Malay entrepreneur of terubuk ikan masin has become one of the successful entrepreneurs in the entrepreneurial field. Even though the number of the entrepreneurs are still small, but the Sarawak Malay entrepreneur of terubuk ikan masin become one of the main contributor to the state tourism activities. Hence, those entrepreneurs still have to face a lot of challenges and obstacles in the business. Thus, this research aims are to identify the challenges faced and the framework with regards to the challenges faced by the Sarawak Malay entrepreneur of terubuk ikan masin. Using qualitative study to understand the challenges that they are faced in line with this business and finding shows the challenges they faced both personally and in business itself during the various stages of business development are location not strategic, economy problem, lack of business knowledge and financial support. Moreover, Sarawak Malay entrepreneur terubuk ikan masin also plays an important role in economic development and income growth because terubuk ikan masin is one of the best products in Sarawak besides multilayer cake. Terubuk ikan masin gives contribution especially in eco-tourism. Hence, these terubuk ikan masin are important estuarine fishes, both commercially and culturally in many Asian countries, including Malaysia. The information that generated from this research will be useful for further studies not only for the future researcher but also for sustainable on commercial fish.
\end{abstract}

Keywords: Ikan Terubuk Masin, Malay entrepreneur, business knowledge, financial support, eco-tourism

\section{Introduction}

Sarawak is well known as its gastronomic cooking styles that can't be found in any other parts of the world and how these foods symbolize the personality of every residence tribe. Sarawak offers a variety of local delicacies and some of it can't be found in some other parts of the world. One of their famous histories is salted terubok ikan masin. Terubuk ikan masin is very popular among the tourist, especially the visitors from peninsula Malaysia, Sabah and Brunei Darussalam, which makes it obligatory souvenir when visiting the land of the hornbills. Salted terubuk masin became one of the famous Malay dishes in Sarawak. Terubuk ikan masin popularity is linked to the fact that long extinct fish from rivers in the peninsula but in Sarawak many species of bony fish can still be found mainly in spawning season between June and October. According to the Agriculture Department (2011), stated that an allocation of RM1.35 million has been given during the current Tenth Malaysia Plan (10MP) to improve Lingga and Semariang Batu fishery stations for research and mass production of terubuk ikan masin fry. In addition, the Ministry of Science, Technology and Innovation had approved funds amounting to RM5.5 million for upgrading of infrastructure and new research and development facilities in Tarat Fishery Station on Empirit breeding. Besides that, the demand of terubuk ikan masin is high especially during holidays and events that been organized by Sarawak tourism such as visit Sarawak, Sarawak International Dragon Boat Regatta and Sarawak Regatta.

Furthermore, terubuk ikan masin is a signature product as a souvenir to visitors who came to Sarawak and became synonymous with Sarawak. In Sarawak, fishing activity is concentrated in near shore muddy areas, and productive fishing grounds can be found in the southern bays and in the north. The fishing season in Sarawak is determined by the northeast monsoon from November to February. Usually within the months it rough for small scale fishers to go fishing because of the condition. Moreover, terubuk ikan masin was formerly found in all the coastal waters and all 
estuaries of river. Besides that, terubuk ikan masin is important for riverine and coastal fishermen because terubuk ikan masin very popular among both local and overseas consumer. However, entrepreneur salted terubuk ikan masin cannot free themselves from such obstacles. Most of the entrepreneur salted terubuk ikan masin are from small scale fisher which mostly at rural area. Some of them there are not are registered company. With the record, only 41,759 registered fishermen in Sarawak (Department of Fisheries, 2009). As the number of entrepreneur salted fish increasing, the Malaysian government has introduced a new environment for the entrepreneur. These will lead to difficulty to some entrepreneurs to adapt to the changing business environment .The problems due to some of the entrepreneur terubuk ikan masin lack in knowledge skill and difficulty in adapting with the new technology. These will create challenges to the entrepreneurs who have not yet embraced the new technology, and who are now finding it hard to remain relevant in the competitive business environment.

\section{Research Problem and Research Objective}

In Sarawak, entrepreneur terubuk ikan masin represents an incredible amount of untapped potential on contribution in economic growth especially in terms of commercial. The Small and Medium Enterprises (SMEs) play a vital role in the development of the Malaysian government's economic growth. SMEs assist in regional and local development as they accelerate industrialization in rural areas by linking them with the more organized urban sector. Small and medium enterprises (SMEs) work in all businesses, yet they vary significantly in their tendency and significance from industry to industry and from nation to nation. The meanings of SMEs additionally fluctuate among countries which is different countries utilized distinctive size standard and diverse criteria to quantify the measure of firms and subsequently, to characterize SMEs. It can be concluded that the major problem in Small Medium Enterprises is their performances. According to the Chee, (1986), he said that the failures arise because they do not practice any form of strategic planning. Strategic planning is very important for the success of an organization. Studies have also shown that the high failure rate among small firms, particularly among start-ups, can be attributed to the lack of formal business planning (Castragiovanni, 1996; Hye, Lau \& Tourres 2014).

Therefore, this sector plays a crucial role in the economy as an engine to generate economic growth in Malaysia. According to the (Department of Statistics, 2005), small and medium enterprises comprise more than $99 \%$ of business establishments and $80 \%$ of them are categorized as micro level. SMEs must consider motivation and strategies facing smaller firms and recognize that these differ from those facing larger firms. Small and Medium Enterprise lack in implementing strategies in develop skills, knowledge and competencies among worker in the small organization. Furthermore, small and medium enterprise lack of career structure in motivation. Therefore, small firms have difficulties to progress and compete with larger firms whereby the employees have low motivation to outperform. This is a major hurdle that SMEs faced especially in developing countries. In other hands, creating effective strategies improve or positively affect the performance of firms. It helps firms to have better competitive advantage over competitors. One of the example SMEs problems is informal status and poor corporate and governance structures. A majority of SMEs in the agriculture sector are informal, making it difficult for banks to gather the information to appropriately evaluate and lend to these groups (Dolgopolova, Hye \& Stewart 2014). Informal and unregistered SMEs can also be risky for banks because their ability to enforce any protection against default is limited. In addition to this, those SMEs that are formalized may lack the corporate or governance structures needed to assure financial institutions that they are bankable (Shujog, 2014; Dincer \& Kilinç 2018).For this research, the specific research objectives are to identify the challenges that been face by entrepreneur terubuk ikan masin conducting the business in a new environment.

\section{Literature Review}

Malaysia is highly moving towards turning into a profoundly industrialized economy, this changing in economic scenario and structure would make it necessary to evaluate the role and contribution of the agricultural sector in the economic development of the country. Malaysia is also honored with the right prolific soil and atmosphere which is exceptionally suitable for agriculture activities. According to Silva (2010), agriculture sector involved in wide array of industries such as farming, breeders, fisheries, food processing, non-food processing, plantation and many more. In agriculture based products, the most popular activities are fisheries and agro based industry. Fisheries and agro based industry is the rise of new contract farming activities such as leech rearing, worms rearing, herbs and mushroom have indeed attracted huge interests from public (Silva et al., 2010; Haseeb,et.al 2019). According to the Deputy Chief Minister Agriculture and Food Industry Minister (2014), entrepreneur fisheries need a new mentality and attitude change to adopt entrepreneurial characteristics. Nowadays, the field of entrepreneurship has been considered as one of the important areas in a country's economic growth including job creation (van Praag and Versloot 2007) and economic development (McMullen, Bagby and Palich 2008; Audretsch 2007; Shu 2001). The 
entrepreneur is a person who bought factors of production for the production of goods to be sold (Othman et al., 2010). According to the Firth (1966) and Ooi (1990), fishing activities were manly small scale making use of traditional fishing gears in shallow inshore areas. Fisheries are an element part of Malaysian society. According to Saharuddin (1995), they provide an affordable source of protein for up to two thirds of Malaysia's population. Fishing activities also central sources of income and employment in rural coastal fishing villages throughout the country, both historically and in present time (Firth 1966; Raduan et al. 2007; Mejdoub \& Arab 2017). In the meantime, in state of Sarawak has a special type of fish that rarely be found in Peninsular Malaysia which is terubuk ikan masin. Terubok ikan masin mostly found in only a few river estuaries and coastal areas of Sarawak and in smaller quantities (Department of Fisheries Ministry Agriculture Malaysia, 1998).

In the early sixties, terubok ikan masin was caught in large quantities during the peak periods in the coastal waters and estuaries of rivers in Malaysia such that sometimes they oversupplied the market (Chua \& Mathias 1978). There are currently five types of the Tenualosa fish that been described based on worldwide which is Tenualosa ilisha, Tenualosa macrura, Tenualosa revesii, Tenualosa thibaudaui and Tenualosa toli (Blaber et al., 2003). These fish are believed to spawn seasonally. According to the Delsman (1921-1938), reported that in the west coast of Peninsular Malaysia the fish migrated into estuaries and further upstream during the spawning season. The terubuk ikan masin produced pelagic eggs and the young hatched out within twenty-four hours. Moreover, young and juvenile terubuk ikan masin were then found in large numbers in mangrove fringed estuaries in the southern part of Peninsular Malaysia. There are two main species of "Ikan Terubok" (or "Shad" in English) found in Sarawak. The species Hilsa macrura (Bleeker) has a small mouth and is locally called "Terubok", whereas the second species Hilsa toli (Valenciennes) has a large mouth and is locally called "Bekawal" (Albert C. Gambang, 1988). In addition, these both species which is Hilsa macrura is usually caught in coastal areas especially around Pulau Burong while Hilsa toli is mostly caught around the estuary and lower region of Batang Lupar. Both of species of "Ikan Terubok" which is Hilsa macrura and Hilsa toli are very important commercial fish, especially to the riverine and coastal fishermen. Terubuk ikan masin usually found in estuaries rivers and coastal areas. The estuaries rivers include Sematan, Lundu, Sadong, Bako, Saribas, Batang Lupar and Muara Lassa. And for the coastal areas include Tanjong Sirik. Pulau Burong, Oya, Mukah, Balingian, Bintulu and Miri. Hence, for the main areas where the fish is presently found in relative abundance are the Batang Lupar river, and the coastal area around Pulau Burong. Terubuk ikan masin is very popular among both local and overseas consumer. Many tourists will buy terubuk ikan masin as their souvenir for their family or friends everytime they come to Sarawak. Terubuk ikanmasin became one of the top five species of fish in the marine fish catch market. Asan important food source to the people of Sarawak, terubok ikan masin has always received prominent attention as a delicacy, be it by the locals or visitors to the state. Mostly entrepreneur salted terubuk ikan masin usually organized their business as a family or have a single proprietor.

However, when the enterprise expands, a partnership normally evolves, leading eventually to the formation of a limited company. The entrepreneur terubuk ikan masin will find the strategic location to starting their business. According to the Federal Agricultural Marketing Authority (FAMA) (2015), most of the entrepreneur terubuk ikan masin registered under their department. Only the Federal Agricultural Marketing Authority (FAMA) has an authority to give the permitted the entrepreneur. According to The Ministry of Agriculture and Food Industry (Borneo Post, 2014; Meutia, Mustika \& Adam 2018), regarding on the development of downstream production of agro based products that the agro based product can be processed and value added. This effort is to provide business opportunities to the rural community to further diversify their income sources with the help and advice of various related departments and agencies. Hence, Federal Agricultural Marketing Authority (FAMA), Malaysian Fishery Development Authority and Farmers Organization Authority build collector's centers which is agro-markets (Pasar Tani) and wholesale markets to reduce the control of middlemen who have been oppressive to farmers, breeders and fishermen (Borneo Post, 2014). Moreover, based on above explanation on terubuk ikan masin, the study need to discuss further on the challenges.

\section{Research Methodology}

Semi-structured interview is the major data collection method used to identify the challenges of Sarawak Malay entrepreneur terubuk ikan masin. Based on Mason, (2002), he said that from the ontological point of view, this study based on the assumption that which is relate to the people knowledge, views, understanding, interpretation, experiences and interaction are meaningful. This is because from the epistemological view, it is assumed that people talking interactively is a meaningful way to create data. A total of 20 informants were purposefully selected from the list of entrepreneur terubuk ikan masin and FAMA database out of 20 informants that have been suggested. The researcher had to see them at Pasar Satok and show them the letter of interviewing. An interview confirmation letter thanking the final listed 10 informants for their interest in participating the interview. The interview letter will 
include about the interview date. The informants were informed and encouraged to notify the researcher if they had any question related to the study or if they needed the researcher to provide additional times and dates on weekends to complete the interview. Under data collection, the informants completed the interviews between 1 hours or less. Informants were asked a broad range of question followed by 15 open ended questions and the corresponding probe for each of the questions. Before interviewed the participants ,permissions were asked from participants to record the interview sessions in order to expediate the flow of the interview to be faster and smoother as well as to capture actual contain of the informant's comments. The recorded interviews were subsequently transcribed by hand and the data converted into a printed form to facilitate further analysis. No information identifying the informants was included in the written copy of interviews. The informant's names were replaced by an identification code on all written materials and electronic data file connected to the research (Creswell \& Clark, 2007). The resulting data included over 15 pages single spaced transcript.

\section{Analysis Data and Findings}

Below is the profile of informants.

Table 1. A list of the entrepreneur terubuk ikan masin informants

\begin{tabular}{ccclc}
\hline Informant & Age & Gender & Race & Years in \\
\hline MA & 31 & Male & Malay & 12 \\
\hline SB & 47 & Male & Malay & 10 \\
\hline AM & 33 & Male & Malay & 7 \\
\hline MD & 24 & Male & Malay & 5 \\
\hline TM & 42 & Male & Malay & 10 \\
\hline FA & 39 & Male & Malay & 10 \\
\hline SU & 48 & Male & Malay & 16 \\
\hline RA & 37 & Female & Malay & 8 \\
\hline AF & 58 & Male & Malay & 22
\end{tabular}

Through the responses on the interview, the researcher found there were two factor of motivation that influenced Sarawak Malay entrepreneur terubuk ikan masin within Pasar Satok, Kuching which is income and surviving. Based on the result findings, it's can be indicated the crucial problem faced by the entrepreneur. In order to know their challenges, the information was sought that its contents various challenges they faced in business itself during the stages of business development. Moreover, it can enable the Sarawak Bumiputera entrepreneurs to receive the necessary support to equip them to overcome the challenges.

\subsection{Inconsistency of Sales Affects the Income of the Entrepreneur}

In this research, the researcher found out the population of Sarawak Malay entrepreneur terubuk ikan masin became entrepreneur because of income. The interviewees who consisted of entrepreneur terubuk ikan masin informed the researcher that their income is one of their motivations to involve in the business. Most of the entrepreneur came from a poor family and live far from the city due to this problem it motivates them to earn more income as the growth of economy is not increasing at a favorable rate.

According to the Ho Tiong Keng (2006), the individual's aspiration to be independent in achieving high business growth for themselves as well as earning more money. It can be indicated that the number of Malay entrepreneurs engaging in business has increased from year to year, especially with the government's continuous effort encouraging Malay to be involved in entrepreneurship (Ismail \& Sulaiman 2007). Based on the finding results on the challenges, it's specifically indicated that Sarawak Malay entrepreneur's terubuk ikan masin motivation leads to the influenced due to the challenges which is lack of business knowledge, financial problem, economic problem and location of business are not strategic enought. All of this challenge will lead to the income of Malay entrepreneur. Runyan et al (2008), stated that business owners are individuals who established and managed business for the purpose of personal goals and agendas as well as to generate family income.Based on the interview, the researcher found out the reason what keep them motivated to proceed in this business. According to Mr TM and Mr MA they 
feel motivated to involve in the business because the wanted to gain more income and expand their business since demands for the ikan terubok masin is attractive.

'I personally feel that I'm motivated to involve in business because I want to find more income so that I can expand my business...'

Mr TM

'In my opinion, I motivate to involve on this business because I want to find more income. I know when I earn more income I can full fill my dream which is to becomes successful entrepreneur of terubuk ikan masin...'

Mr MA

Moreover, the respondents also stated that most of entrepreneurs were pushed into business to generate income to provide for them and expand their business successfully. As one of the interviewees explained:

'What make me motivated to involve in this business because my monthly salary are not enough for me to expand my business more further...'

$\mathrm{Mr} \mathrm{AF}$

\subsubsection{Issues on Location Not Strategic}

During the interview, the entrepreneur told the researcher that one of their challenges that they have to face as an entrepreneur of terubuk ikan masin is the location of the business. The government association namely FAMA has located them in a new location for their business of terubuk ikan masin. They were relocated to a new business environment location which is not strategic located to sell their product. In the interviews, most of the entrepreneurs of terubuk ikan masin faced the same challenges. Most of the entrepreneur preferred the old placed compared to the new placed as the entrepreneur told the researcher that they cannot earned a lot of income in the new placed compared to their old placed they can gain money around RM 10,000 in a month. For example, Mr SB told that the location of the place is not very suitable for the entrepreneur of terubuk ikan masin and the foreign visitors and the local peoples will not be attracted to come over. Moreover, during the interview one of the entrepreneur complained that the location is not strategic because of the location is far from the city. As Mr TM said:

'The biggest issues that I faced is the location is not strategic for selling terubuk ikan because of location is quite far from the city it will due to the cost of transportation...'

Mr TM, 42

Other opinion from the interviewee that is Mr AF indicated that the same reason with Mr TM. According to him:

'I think not strategic location is one of the challenges that been faced by the entrepreneur of Terubuk ikan masin because of the location is far from the city and it's hard for the buyer to pass by....'

Mr AF, 58

Other than that, other opinion from Mr FA and Mr MN also state that not strategic location might be challenges for them.

'Common problem that been faced is not strategic location. I believed the location is not easy to locate. Even my regular client asked me about the location...'

Mr FA, 39

'As for me the location is not really strategic from the old location it is because the old location is easy to locate and the outsider and the local people also easy to find the location...'

$\operatorname{Mr} \mathrm{AM}, 33$

\subsubsection{Lack of Financial Support}

Sarawak Malay entrepreneur terubuk ikan masin always confronted with the difficult situation in the business. During the interviews, the respondent told the researcher that lack of financial support was a challenge for them around Pasar Satok, Kuching Sarawak. However, the findings from most of the interview responses indicated that access to loan or credit, personal savings and sourcing. They explained that it was difficult to access to bank loan because most of them come from the village and it is hard for the banker to believe in them. Some of the comments supporting this are stated as follows:

'I'm using my own money to start the business without any support from others especially from government. It's really disappointed me that government did not provide anything accept the location...'

$\mathrm{Mr}$ SB, 47 
I never tried to apply any credit loans from any bank to support my capital because I know bank have trust issues with us. Because probably we are come from a small village...'

Mr TM, 42

While the other, Sarawak Malay entrepreneur terubuk ikan masin such as Mr AF, Mr FA and Mr MN were not interested to obtain loan. They refused to obtain loan because of the interest rate charged by bank especially commercial banks. The commercial bank usually charged higher interest rate to the loaner and the term of the payment is shortened and it will cause the loaner not interested to make a loan to the banks. Due to these difficulties, Sarawak Malay entrepreneur of terubuk ikan masin used other finances method such as personal saving to start and grow their businesses. One of the respondents has starting his business over 6 years but him still using their own personal savings to expand his business. Hence, from the analysis this is some comment that supporting this state:

'I received nothing for financial support for startup my business. I really need some support to expand my business. Otherwise, I will only stay old my business as terubuk ikan masin only and cannot expand my business...'

Mr AF, 58...

'The financial assistance to me does not cover anything for my business. It is only providing the location which is not strategic place to sell terubuk ikan masin...'

Mr FA, 39

'I didn't apply any credit loans because I knew it will be complicated and I also lack about any financial knowledge. So I'm using my own money to start my business and when crucial time I had to work other job became my financial support...'

Mr, 33

\subsubsection{Lack of Business Knowledge}

From the interview, the researcher found that most of the respondents were lacking of management experience, financial planning, business or strategic planning, communication skills for marketing. It can show from interview data that some of the Sarawak Malay entrepreneur terubuk ikan masin have law level of knowledge in all major aspect which could be one of their challenges. This finding is supported by the Buerah Tunggak (2011) which illustrates that knowledge and entrepreneurial management skills are major weaknesses of Malay SME entrepreneurs.

'When I'm started doing my business, I don't have any knowledge about how to manage any business successfully such as finance, communication and marketing...'

Mr SB, 47

'Based on my opinion, I think the biggest challenge is lack of knowledge because most of entrepreneur terubuk masin they came from village so they very low in knowledgeable...'

Mr TM, 42

I never attend any classes before involved in this business. But I manage to learn from customer suggestion and complaint about my services even though sometimes it little bit stressful...'

$\operatorname{Mr} \mathrm{MN}, 33$

\subsubsection{Economy Problem}

Furthermore, economy problem has affected the income earning of the terubok masin is entrepreneur. Economy problem is one of the challenges faced by the entrepreneur. Due to the economy problem, the wholesaler increased a higher price to the product among the entrepreneur. The high increase of price level of the goods and services will affect the income of the entrepreneur of terubuk ikan masin. Hence, due to this problem, the entrepreneur had to increase the price of their product to their customer and because of this the demand of terubuk ikan masin decreased. Based on Mr AF and Mr FA:

'I do think that economic problem will affect it our situation because all the prices that involving the fish will be high and it's difficult for us to maintain our business especially in financial...'

$\mathrm{Mr} \mathrm{AF}, 58$

'Based on my opinion, I think economic problem it's one of the challenges that been faced by ours because when the economic have problem situation the price of the fish will be high. So it's will difficult to maintain the buyers because some of them they did not understand the situations that make us to mark up the prices of the fish...'

Mr FA, 
Moreover, it's also effect the customer perception over the price increase of ikan terubok masin. For example, some of the customer they don't understand the reason why the entrepreneur needs to mark up the prices. Even though the customer alert with the economic situation, they still can't accept when the entrepreneur marks up the prices. When a country having economic problem, everything will be changed such as taxes, cost of the supplier terubuk ikan masin and sale of the terubuk ikan masin. It's really hard to maintain stability in financial of the sales because terubuk ikan masin is categorized as seasonal product so when during non-festive season, sales of terubuk ikan masin is not really good. This is some of the statements from the respondent as follows:

'Based on my experiences in this business, problem situation in economic growth is one of the reasons in challenges. The government will increase the cost of the taxes. So its will difficult for me to maintain my financial stability because this business is seasonal product where it's will good on festive season only...'

Mr MN, 33

'Increasing economic growth will affect the rising in price of terubuk masin. When it's come to maintain the stability of sales terubuk ikan masin. It's is because the sales of terubuk ikan masin only good during festive people...'

$\mathrm{Mr} \mathrm{SB}, 47$

'The sales of terubuk ikan masin depend on the economic growth of the country. Due to the higher prices in all cost, an example when comes to supplying cost on the fish. It's really hard to survive if have problem in economic growth...'

Mr TM, 42

\section{Conclusion and Recommendation}

As a conclusion, based on the finding results, the major factor that effected on Sarawak Malay entrepreneur terubuk ikan masin is unsuitable location, financial support, economic problem and lack of business knowledge. This is the major challenges faced by the entrepreneurs. Sarawak Malay entrepreneurs need to overcome the challenges because it affect their earning income for themselves $n$ family and also to survive in the business. According to Suraiya Ishak (2012), he said that the pursuit of the turning point is a challenging phase because at this point there is a range of problems that must be dealt with efficiently and effectively and these all take some time. On other hands, all parties must work together to assist Malay entrepreneurs in addressing their problems in order for their businesses to compete in the market.

Additionally, these challenges will hinder them to become potential successful entrepreneurs. These challenges can be effectively overcome by the entrepreneurs if they know how to expand the business successfully by starting to create effectively strategies. Moreover, the high level of the education regarding on the profession make the business grows successfully. So, regarding on the challenges lack in business knowledge, it's can be said that if the entrepreneurs high level based on the profession its make them potential to make their business became successfully. It does can make them potentially to create a new idea and became as innovates as well in improving standard of living. Related to my research question, based on the interview the respondent only answers the question about the challenges faced by them and their motivations in their business. Meanwhile, the respondent cannot answer the question about their strategies to overcome their problem because they do not know to plan a strategy on how to overcome the challenges been face by them. Hence, based on the finding it's found that the majority of the entrepreneur has lack of business knowledge and low education level. Furthermore, all the parties must work together to assist Malay entrepreneurs in addressing their problem in the field small and medium entrepreneurs (SME) in order for the business to compete in the market. Critical success can be identified through this problem.

\section{References}

Blaber, S. J. M., Milton, D. A., Chenery, S. R., \& Fry, G. (2003). New insights into the Life History of Tenualosa ilisha and Fishery Implications.

Buerah Tunggak, Hussin Salamon, \& Baharin Abu. (2011). Training and long life learning for Islamic entrepreneur. Jurnal Teknologi, 55 (Sains Sosial), Halaman, 121-144. https://doi.org/10.11113/jt.v55.84

Castrogiovanni, G. J. (1996). Pre-startup planning and the survival of new small businesses: Theoretical linkages. Journal of Management, 22(6), 801-822. https://doi.org/10.1177/014920639602200601

Chee Peng Lim. (1975). The Role of Small Industry in the Malaysia Economy. Unpublished Doctoral dissertation, University Malaya.

Chua, T-E., \& Mathias, J. A. (1978). Evaluation of the impacts of oil spill on coastal resources. In Coastal resources of West Sabah- an investigation into the impact of oil spill (pp. 262-267). Penerbit Universiti Sains Malaysia, Penang Malaysia. 
Creswell, J. W., \& Clark, V. L. P. (2007). Designing and Conducting Mixed Method Research. Thousand Oaks: Sage Publication.

Delsman, H. C., \& Firth, R. (1966). House Keeping Among Malay Peasants. University of London, the Athlone Press, New York: Humanities Press Inc

Deputy Chief Minister Agriculture and Food Industry Minister. (2014). Farmers, Breeders, Fishermen Urged to Be Entrepreneurs, 1 Nov. 2014, 10. Web.

Dincer, N., \& Kilinç, Z. (2018). The Analysis of Stress Levels of the Female Wrestlers Studying in Higher Education (A Case of Batman Province). Asian Journal of Education and Training, 4(3), 156-160. https://doi.org/10.20448/journal.522.2018.43.156.160

Dolgopolova, I., Hye, Q. A. M., \& Stewart, I. T. (2014). Energy consumption and economic growth: evidence from non-OPEC oil producing states. Quality \& Quantity, 48(2), 887-898. https://doi.org/10.1007/s11135-012-9810-4

Firth, R. (1966). Malay fishermen-their peasant economy. Routledge and Reagan Paul, London.

Gambang, A. C. (1988). Some aspects of the biology of Ikan Terubok, Hilsa toli (Valenciennes) (Family: Clupeidae) at the Lower Batang Lupar River, Sarawak.

Haseeb, M., Zandi, G., Hartani, N. H., Pahi, M. H., \& Nadeem, S. (2019). Environmental Analysis of the Effect of Population Growth Rate on Supply Chain Performance and Economic Growth of Indonesia. Ekoloji, 28(107), 417-426.

Ho Tiong Keng. (2006). Bachelor of Economics with Honors (International Business \&Economics). The motivational needs of entrepreneurship in Malacca.

Hye, Q. M. A., Lau, W. Y., \& Tourres, M. A. (2014). Does economic liberalization promote economic growth in Pakistan? An empirical analysis. Quality \& Quantity, 48(4), 2097-2119. https://doi.org/10.1007/s11135-013-9882-9

Ismail, R., \& Sulaiman, N. (2007). Technical efficiency in Malay manufacturing firms. International Journal of Business Society, 8(2), 24-37.

Mason, J. (2002). Qualitative researching (2nd ed.). London: Sage Publications.

Mejdoub, H., \& Arab, M. B. (2017). A multivariate analysis for risk capital estimation in insurance industry: Vine $\begin{array}{lllll}\text { Copulas. Asian Development Policy } & \text { Review, } & \text { 5(2), } & \text { 100-119. }\end{array}$ https://doi.org/10.18488/journal.107.2017.52.100.119

Meutia, I., Mustika, S., \& Adam, M. (2018). Cultural Relevance to Sustainability Reporting in Asian and European Banking. Journal of Accounting, Business and Finance Research, 4(1), 9-19. https://doi.org/10.20448/2002.41.9.19

Raduan, M., Sharir, M., \& Aziz, Z. (2007). Masalah nelayan tradisional di Semenanjung Malaysia: Penyelesaian Tanpa Kesudahan. Jurnal Jabatan Pengajian Asia Tenggara, 12, 247-258.

Runyan, R., Droge, C., \& Swinney, J. (2008). Entrepreneurial orientation versus small business orientation: What are their relationships to firm performance?. Journal of Small Business Management, 46(4), 567-588. https://doi.org/10.1111/j.1540-627X.2008.00257.x

Saharuddin, A. H. (1995). Development and management of Malaysian marine fisheries: Technical conservation measures. Mar. Policy, 19(2), 115-126. https://doi.org/10.1016/0308-597X(94)00011-G

Shujong. (2014). Small and Medium Enterprises in Agriculture Value. Retrieved from http://shujog.org/wp-content/uploads/2011/08/OXFAM-SME-Report-Novemb er- 201_FINAL.pdf

Silva, J. L., Mohamad Shaffril, H. A., Uli, J., \& Abu Samah, B. (2010). Socio-demography factors that influence youth attitude towards contract farming. American Journal of Applied Sciences, 7(4), 603-608. https://doi.org/10.3844/ajassp.2010.603.608

Suraiya Ishak, Ahmad Raflis Che Omar, \& Azhar Ahmad. (2012). Tales of the survivors: the Bumiputera entrepreneur's' experience. Asian Social Science, 8(3), 25-33. https://doi.org/10.5539/ass.v8n3p25

Van Praag, C., \& Versloot, P. (2007). What is the value of entrepreneurship? A review of recent research. Small Business Economics, 29(4), 351-8. https://doi.org/10.1007/s11187-007-9074-X 